\title{
Designing Support to Facilitate Learning in Powerful Electronic Learning Environments
}

Citation for published version (APA):

Kester, L., Kirschner, P. A., \& Corbalan, G. (2007). Designing Support to Facilitate Learning in Powerful Electronic Learning Environments. Computers in Human Behavior, 23(3), 1047-1054.

https://doi.org/10.1016/j.chb.2006.10.001

DOI:

10.1016/j.chb.2006.10.001

Document status and date:

Published: 01/05/2007

Document Version:

Peer reviewed version

Please check the document version of this publication:

- A submitted manuscript is the version of the article upon submission and before peer-review. There can be important differences between the submitted version and the official published version of record. People interested in the research are advised to contact the author for the final version of the publication, or visit the DOI to the publisher's website.

- The final author version and the galley proof are versions of the publication after peer review.

- The final published version features the final layout of the paper including the volume, issue and page numbers.

Link to publication

\section{General rights}

Copyright and moral rights for the publications made accessible in the public portal are retained by the authors and/or other copyright owners and it is a condition of accessing publications that users recognise and abide by the legal requirements associated with these rights.

- Users may download and print one copy of any publication from the public portal for the purpose of private study or research.

- You may not further distribute the material or use it for any profit-making activity or commercial gain

- You may freely distribute the URL identifying the publication in the public portal.

If the publication is distributed under the terms of Article 25fa of the Dutch Copyright Act, indicated by the "Taverne" license above, please follow below link for the End User Agreement:

https://www.ou.nl/taverne-agreement

Take down policy

If you believe that this document breaches copyright please contact us at:

pure-support@ou.nl

providing details and we will investigate your claim.

Downloaded from https://research.ou.nl/ on date: 26 Apr. 2023 
Running head: DESIGNING SUPPORT

This is a pre-print of the article that was published as:

Kester, L., Kirschner, P. A., \& Corbalan, G. (2007). Designing Support to Facilitate Learning in Powerful Electronic Learning Environments: Introduction. Computers in Human Behavior, 23, 1047-1054.

Copyright Elsevier, available online at http://www.elsevier.com/wps/find/journaldescription.cws_home/759/description\#description

Designing Support to Facilitate Learning in Powerful Electronic Learning Environments: Introduction

Liesbeth Kester $^{1}$, Paul Kirschner ${ }^{1,2}$, and Gemma Corbalan ${ }^{1}$

${ }^{1}$ Educational Technology Expertise Center, Open University of the Netherlands

${ }^{2}$ Research Center Learning in Interaction, Utrecht University 
Designing Support

Abstract

This themed issue reflects current developments in instructional design for powerful electronic learning environments. It presents a compilation of contributions to a combined special interest group (sig) meeting (2006) of Instructional Design and Learning and Instruction with Computers. Both sigs are part of the European Association for Research on Learning and Instruction (EARLI). The sigmeeting focused on the design of powerful electronic learning environments for complex learning. The articles in this issue describe how to design support to help learners during complex individual or collaborative learning. This introduction provides the context for the issue and a short overview of the contributions. 
Designing Support to Facilitate Learning in Powerful Electronic Learning Environments: Introduction Modern curricula are increasingly making use of powerful electronic learning environments to facilitate complex learning. Such environments stimulate active learning - knowledge construction by learners based on their cognitive and social activities in meaningful contexts (Brown, Collins \& Duguid, 1988) - by giving learners control over an environment containing varied information resources such as texts, auditory fragments, and animations (Merrill, 2002; Reigeluth, 1999; van Merriënboer \& Kirschner, 2001) and realistic learning tasks such as simulations and games. These environments enable a qualitatively different way of learning compared to traditional learning environments (i.e., traditional classes and textbooks).

In contrast to the traditional learning environments that usually offer compartmentalized (i.e., practice knowledge, skills and attitudes separately), and fragmented (i.e., part-task practice of subskills) learning tasks, powerful learning environments provide realistic, authentic learning tasks that are characterized by integration (i.e., training knowledge, skills and attitudes simultaneously), and coordination (i.e., whole-task practice of constituent subskills). Such realistic learning tasks help learners transfer what is learned to situations outside school (van Merriënboer, 1997). In addition, modern environments allow for learning in a non-linear fashion by giving learners more control over their own learning. Learners are enabled to select information, tasks, instructional formats (e.g., video, audio, graphic, or text), interface properties, and content (e.g., examples, analogies) in their preferred order and at their own pace (Merrill \& David, 1994).

This development in instructional design makes learning more difficult. Realistic, authentic learning tasks put a higher burden on the cognitive capacity of learners than compartmentalized and fragmented learning tasks and a high level of learner control over the instructional material requires a high level of self-regulation ability and domain expertise from them. However, an emphasis on integration and coordination of knowledge, skills and attitudes during practice pays off in a higher transfer performance (for an overview see van Merriënboer \& Kester, 2006; van Merriënboer, Kester \& Paas, 2006). Moreover, putting learners in control of their own learning is believed to help them 'learn how to learn' (Merrill \& David, 1994) and increases their motivation to engage in activities relevant for learning (Deci, Vallerand, Pelletier, \& Ryan, 1991; Corbalan, Kester \& van Merriënboer, 2006). 
Because of these discrepancies, it is necessary to carefully consider the role of guidance and support in the design of powerful electronic learning environments to balance the pros and cons of an integrated, coordinated approach to practice with learner control over instructional material.

Realistic learning tasks

An integrated and coordinated approach to practice design results in the development of realistic, authentic learning tasks that give learners the opportunity to simultaneously acquire knowledge, skills and attitudes necessary for successful performance. Such tasks are characterized by a high element interactivity, this means that a learner has to process several learning elements simultaneously in order to achieve a sufficient performance on the task (Sweller, van Merriënboer, \& Paas, 1998; van Merriënboer \& Sweller, 2005). Compartmentalized and fragmented learning tasks are often characterized by a low element interactivity which allows learners to serially process several learning elements for sufficient performance. Since working memory is severely limited with regard to the maximum number of simultaneously active elements it can hold (Cowan, 2001), it is clear that realistic learning tasks demand more cognitive capacity than tasks with a low element interactivity. If a realistic task is too complex, as indicated by its element interactivity, working memory could be overloaded which hampers learning (Sweller, 1988). To avoid this, one could either reduce the amount of element interactivity without loosing the realistic aspects of the learning task or add support to the learning task.

First, the amount of element interactivity may be initially reduced by simplifying the tasks, after which more and more elements and interactions are added (i.e., a part-whole approach). So, such a task sequence begins with the simplest version of a task that is still representative of the task as a whole and ends with the most complex version of this task (Reigeluth, 1999). For example, learners start studying the anatomy and functioning of the circulatory system on an organ level (e.g., heart, blood vessels, arteries), and end studying the circulatory system on a cell level (e.g., red/white corpuscles, trombocytes). Or, the task may be immediately presented in its full complexity while the element interactivity is reduced by having the learner take more and more interacting elements into account when performing it (i.e., a whole-part approach). During a first driving lesson, for example, 
learners drive a car in traffic but they only have to steer and brake while during the last lesson they have to independently operate the car.

In addition to or apart from these measures to lower the element interactivity of a learning task one could add support to it to avoid cognitive overload and help learners manage task complexity. Seufert, Jänen and Brünken, and Munneke, Andriessen, Kanselaar and Kirschner added graphical support to facilitate learning from complex tasks in powerful electronic learning environments. In their article "The impact of intrinsic cognitive load on the effectiveness of graphical help for coherence formation", Seufert and colleagues describe three studies that investigated the effect of graphical support on learning material with a high element interactivity. Inter-representational hyperlinks hyperlinks that display connections between representations when clicked on - were used to help learners mentally integrate multiple representations (e.g., text, pictures, graphic organizers) that are mutually referring. The effectiveness of this support in relation to the learners prior knowledge was studied.

The article of Munneke and colleagues titled "Supporting interactive argumentation: Influence of task design on discussing a wicked problem" focuses on graphical support to help groups discuss complex problems in a computer-supported collaborative learning environment. They assumed that graphical support in the form of an argumentative diagram puts a group discussion on a higher plane than support in the form of a text outline. They compared the breadth and depth of the discussions of the diagram groups and the outline groups to verify this assumption.

Huk and Steinke introduce a visualization technique to aid learners during a complex learning task and compare it to graphical support. Their article - "Close-up views and connecting lines as visualization techniques in a complex learning task: Evidence for the structure mapping effect" - describes the effect of zooming in and out between cell and cell organelles as compared to connecting lines between cell and respective technical term (see also Seufert et al.) on learning in a hypermedia learning environment. Both techniques aim at directing learners' attention to relevant aspects of a picture during a narrated explanation of that picture and it is examined which one is most beneficial for learning. 
Research shows that the intrinsic motivation to learn increases when the locus of control over instructional material is transferred from an instructional agent (e.g., teachers, computers) to the learner (Kinzie, Sullivan, \& Berdel, 1988; Reeve, Hamm, \& Nix, 2003). This results in a more satisfactory learning experience which ultimately leads to an improved academic performance. In other words, learner control is an essential aspect of effective learning (Gray, 1987; Lawless \& Brown, 1997; Lou, Abrami, \& d'Apollonia, 2001). However, other research indicates that learners with the highest degree of learner control learned the least (Fry, 1992). So, although learner control has undeniable positive effects on motivation, its effect on learning outcomes is equivocal.

It appears that self-regulation ability and level of expertise mediate the effects of learner control on learning outcomes. Research of Hofer, Yu and Pintrich (1998) indicates that most learners have difficulty self-regulating their own learning. In addition, domain novices possess weak domainspecific cognitive schemata. They usually do not have a good impression of what there is to know about a particular learning task (Ormrod, 2004) and therefore cannot determine which information might help them to carry it out. This interferes with their ability to make effective instructional decisions. In a study of Lawless and Kulikowich (1995; as cited in Lawless \& Brown, 1997), for example, domain novices focused more on the multimedia material (e.g., sound effects) that was irrelevant for learning than on the presented text that was relevant for learning in a specific e-learning environment. More experienced learners, however, do possess adequate cognitive schemata and therefore are less apt to make ineffective instructional decisions and better able to control their own learning. Because of this, it is believed that as levels of expertise increase through experience, instructional-agent control should diminish in favour of learner control (see for a review, Niemiec, Sikorski, \& Walberg, 1996).

So, what support can be offered to help learners self-regulate their learning and optimize the positive effects of learner control in powerful electronic learning environments? The article by Janssen, Erkens and Kanselaar - "Visualization and discussion processes during computer-supported collaborative learning" - reports a visualization technique to support discourse in a computersupported collaborative learning environment. Their visualization tool called "Shared Space" visualized agreement and debate during an ongoing discussion of "The first four centuries of 
Designing Support

Christianity”. The researchers assumed that such a visualization guides the group learning-process and enhances the quality of the discussion. They compared groups that had a discussion with and without access to the "Shared Space" to find out which discussion-quality aspects were affected by this tool. Narciss, Proske and Koerndl, and van Berlo, Lowyck and Schaafstal implemented process support in a powerful electronic learning environment and in a computer-based environment respectively to help learners/users regulate their activities. The Narciss and colleagues article - "Promoting self-regulated learning in web-based learning environments" - presents exploratory results on the use of tools that aim at (1) facilitating orientation and navigation (e.g., location, content structure) and (2) promoting active and elaborated learning activities (e.g., note taking, highlighting) and meta-cognitive activities (e.g., progress and task report) in a learner controlled web-based environment. They expect that proper use of these tools will eventually lead to enhanced self-regulated learning.

The article by van Berlo and colleagues, titled "Supporting the instructional design process for team training", discusses the implementation of specific guidelines in a small design course for team training. These guidelines are intended to help instructional designers regulate their design activities and focus on relevant team-task and -work aspects. They assumed that following the guidelines would improve the resulting team-training blueprint and this was investigated by comparing the training blueprints of designers who had these guidelines to their disposal and those who did not.

\section{Discussion}

The discussion article of Clarebout and Elen closes this issue. We hope that the set of articles presented in this themed issue convincingly show that adding adequate support to powerful electronic learning environments help learners become actively involved in their own learning process with beneficial effects on their learning outcomes. 
References

Brown, J.S., Collins, A., \& Duguid, P. (1989). Situated Cognition and the culture of learning. Educational Researcher, 18, 32-42.

Corbalán, G., Kester, L., \& Van Merriënboer, J. J. G. (2006). Towards a personalized task selection model with shared instructional control. Instructional Science, 34, 399-422.

Cowan, N. (2001). The magical number 4 in short-term memory: A reconsideration of mental storage capacity. Behavioral \& Brain Sciences, 24, 87.

Deci, E. L., Vallerand, R. J., Pelletier, L. G., \& Ryan, R. M. (1991). Motivation and education: The self-determination perspective. Educational Psychologist, 26(3), 325-346.

Fry, J. P. (1972). Interactive relationship between inquisitiveness and student control of instruction. Journal of Educational Psychology, 63, 459-465.

Gray, S. J. (1987). The effects of sequence control on computer learning. Journal of Computer-based Instruction, 14(2), 54-56.

Hofer, B. K., Yu, S. L., \& Pintrich, P. R. (1998). Teaching college students to be self-regulated learners. In D. Schunk \& B. Zimmerman (Eds.), Self-regulated learners: From teaching to self-reflective practice (pp. 57-85). New York: Guilford.

Kinzie, M. B., Sullivan, H.J., \& Berdel, R. L. (1988). Learner control and achievement in science computer-assisted instruction. Journal of Educational Psychology, 80, 299-303.

Lawless, K.A., \& Brown, S.W. (1997). Multimedia learning environments: Issues of learner control and navigation. Instructional Science, 25, 117-131.

Lou, Y., Abrami, P. C., \& d'Apollonia, S. (2001). Small group and individual learning with technology: A meta-analysis. Review of Educational Research, 71, 449-521.

Merrill, M. D. (2002). First principles of instruction. Educational Technology, Research and Development, 50(3), 43-59.

Merrill, M. D., \& David, G. T. (1994) Instructional design theory. Englewood Cliffs, NJ: Educational Technology Publications.

Niemiec, P, Sikorski, C., \& Walberg, H. (1996). Learner-control effects: A review of reviews and a meta-analysis. Journal of Educational Computing Research, 15, 157-174. 
Ormrod, J. E. (2004). Human Learning (4th ed.). Upper Saddle River, NJ: Pearson Education.

Reeve, J., Hamm, D., \& Nix, G. (2003). Testing models of the experience of self-determination in intrinsic motivation and the conundrum of choice. Journal of educational psychology, 95, 375-392.

Reigeluth, C. M. (1999). The elaboration theory: Guidance for scope and sequence decisions. In C. M. Reigeluth (Ed.), Instructional design theories and models. A new paradigm of instruction (1st ed., pp. 425-453). Mahwah, New Jersey: Lawrence Erlbaum Associates.

Sweller, J. (1988). Cognitive load during problem solving: Effects on learning. Cognitive Science, 12, 257-285.

Sweller, J., Van Merriënboer, J. J. G., \& Paas, F. (1998). Cognitive architecture and instructional design. Educational Psychology Review, 10(3), 251-296.

Van Merriënboer, J. J. G. (1997). Training complex cognitive skills: A four-component instructional design model for technical training. Englewood Cliffs, NJ: Educational Technology Publications.

Van Merriënboer, J. J. G., Kester, L. \& Paas, F. (2006). Teaching complex rather than simple tasks: Balancing intrinsic and germane load to enhance transfer of learning. Applied Cognitive Psychology, 20, 343-352.

Van Merriënboer, J. J. G., \& Kirschner, P. A. (2001). Three worlds of instructional design: State of the art and future directions. Instructional Science, 29, 429-441.

Van Merriënboer, J. J. G., \& Sweller, J. (2005). Cognitive load theory and complex learning: Recent developments and future directions. Educational Psychology Review, 17, 147-177. 
Designing Support

Author Note

Correspondence concerning this article should be addressed to Liesbeth Kester, Educational Technology Expertise Center, Open University of the Netherlands, P.O. Box 2960, 6401 DL Heerlen, The Netherlands. E-mail: liesbeth.kester@ou.nl 